\title{
ANALISIS STUDI KELAYAKAN BISNIS USAHA WARALABA DAN CITRA MEREK TERHADAP KEPUTUSAN PEMBELIAN “ALPOKATKOCOK_DOUBIG” DI MAKASSAR
}

\author{
Besse Faradiba $^{1 *}$, Musmulyadi $^{2 * *}$ \\ ${ }^{1,2}$ Fakultas Ekonomi dan Bisnis Islam IAIN Parepare \\ "bessefaradiba@iainpare.ac.id \\ ***musmulyadi@iainpare.ac.id
}

\begin{abstract}
ABSTRAK
Penelitian ini bertujuan untuk mengetahui dan menganalisis kelayakan investasi pengembangan usaha Alpokatkocok_Duobig sebelum menjalankan usaha untuk meminimalisirkan resiko kedepannya, dengan menggunakan metode analisis kelayakan pada aspek pasar pemasaran, aspek manajemen sumberdaya manusia, aspek teknis dan teknologi, aspek hukum, aspek keuangan berupa Analisa kelayakan investasi payback period (PP), Benefit Cost Ratio (BCR), Net Present Value(NPV) dan Internal Rate of Return (IRR) untuk mencari tingkat bunga. Pada penelitian ini teknik sampling yang digunakan dalam penentuan sampel adalah non random sampling dan convenience sampling dengan kuota atau proporsional Berdasarkan dengan Analisa kelayakan bisnis di peroleh hasil Payback Period lebih cepat dari umur ekonomis pengembalian modal. BCR yang menunjukkan memberikan keuntungan, NPV bernilai positif lebih besar dari tingkat bunga yang telah di tetapkan sehingga usaha ini layak untuk di jalankan. Kemudian untuk dalam segi pemasaran dimana citra merek terdapat pengaruh positif terhadap keputusan pembelian, diperlukan penelitian lanjutan untuk mengetahu variable lain yang mempengaruhi keputusan pembelian pada studi kelayakan bisnis ini.
\end{abstract}

Kata Kunci: Analisis Payback Period, Internal Rate of Return, Net Present Value.

\section{PENDAHULUAN}

\section{A. Latar Belakang}

Kondisi lingkungan yang sangat dinamis dan intensitas persaingan yang sangat ketat membuat seseorang terpacu untuk membuat bisnis yang tidak cukup hanya mengandalkan pengalaman dan intuisi saja dalam memulai usahanya. Dalam memulai usaha seseorang harus memiliki gambaran berupa studi kelayakan bisnis untuk mendapatkan gambaran baik laba atau rugi dalam memulai bisnis serta bisnis ini layak untuk dilaksanakan atau tidak sehingga mampu memberikan manfaat kepada pemangku kepentingan (stakeholder).

Usaha Kecil dan Menengah (UKM) adalah unit usaha yang dikelola baik dalam masyarakat maupun keluarga yang merupakan mayoritas pelaku bisnis di Indonesia. Peran dari UKM ini sangat penting dalam pembangunan ekonomi nasional karena selain memberikan kontribusi terhadap pertumbuhan ekonomi nasional juga dapat membuka lapangan kerja dalam jumlah yang besar serta mendorong pertumbuhan ekspor (Lusty, 2012).

Usaha Kecil dan Menengah (UKM) pada bidang makanan begitu berkembang di berbagai kota terutama di Makassar. Semua orang pasti menyukai makanan yang di hasilkan oleh UMKM di makassar apalagi memiliki rasa yang nikmat dan unik karena mendorong rasa penasaran masyarakat untuk mencobanya sehingga banyak usaha makanan unik yang bermunculan baik dalam sistem pemasaran yang tradisional 


\section{PAY Jurnal Keuangan dan Perbankan. Vol. 2 No. 2, Desember 2020}

maupun dengan sistem waralaba (franchise).

Salah satu bisnis waralaba yang cukup bersaing di bidangnya dalam hal minuman adalah Alpokatkocok_duobig. Bisnis waralaba ini berdiri sejak tahun 2014 dan memiliki sepuluh cabang di Sulawesi dan satu Cabang di Ambon. Bisnis Waralaba ini memiliki banyak pesaing namun mampu memenagkan persaingan yang ketat dan meraih keuntungan yang kompetitif karena mampu bertahan hingga memiliki banyak cabang di berbagai daerah. Bisnis waralaba ini dalam sebulan mampu menghabiskan $1600 \mathrm{~kg}$ dengan penjual hinga 150 cup sehari mulai harga RP. 20.000 hingga Rp. 45.000 per cupnya.

Alpukat merupakan salah satu minuman fungsional. Minuman fungsional adalah minuman yang mengandung unsur-unsur zat gizi dan memiliki efek positif terhadap kesehatan (Mustikaningtyas dan Tri, 2015) Minuman Alpokat Kocok tergolong unik karena minuman ini berasal dari Medan hal inilah yang mendorong masyarakat penasaran untuk mencobanya. Produk alpukat adalah produk minuman kekinian yang kaya akan manfaat dan gizi, dihaluskan kasar dan di tambah banyak variasi topping di atasnya dan diinovasikan dengan menggabungkan bahan dasar dengan toping Nangka, durian dan weap cream. Owner bisnis waralaba ini mampu mempertahankan usahanya dengan terus menginovasikan minumannya dengan berbagai ide-ide menarik.

Sistem waralaba yang di tawarkan pada bisnis ini begitu menguntungkan karena branding dan image sudah lama terbangun pada masyarakat makassar. Telah banyak yang berhasil pada setiap cabang alpokatkocok_duobig selain branding yang sudah terkenal, lokasi strategis dan pelayanan serta kualitas minuman juga menentukan keberhasilan usaha ini, sehingga dibutuhka penelitian analisis studi kelayakan bisnis usaha waralaba Alpokatkocok_Duobig untuk mengetahui apakah rencana membangun usaha ini layak atau tidak untuk dilaksanakan.

Dalam suatu perekonomian yang kompleks seperti sekarang ini, seseorang harus mampu mencari peluang untuk membangun sebuah bisnis yang menguntungkan untuk memperoleh laba yang di dapatkan dari penghasilan dan biaya- biaya yang dikeluarkan selain ini dalam bisnis seseorang harus mampu menghadapi tantangan serta resiko untuk mengkombinasikan antara tenaga kerja, material, modal dan manajemen secara baik sebelum memasarkan sebuah produk sehingga dibutuhkan studi kelayakan bisnis sebelum mengambil langkah untuk menjalankan bisnis (Kashmir dkk, 2012).

Perumusan masalah yang diangkat dalam bisnis ini adalah perhitungan analisis kelayakan usaha sebagai awal perencanaan keuangan sebelum mengambil langkah untuk menjalankan bisnis ini.

Tujuan penelitian yang ingin dicapai adalah untuk mengetahui dan menganalisis kelayakan investasi pengembangan usaha Alpokatkocok_Duobig.

\section{B. Rumusan Masalah}

Berdasarkan latar belakang yang diuraikan tersebut, maka rumusan masalah dalam penelitian ini adalah:

1. Bagaimana pengaruh studi kelayakan bisnis usaha waralaba terhadap keputusan pembelian masyarakat Makassar?

2. Bagaimana pengaruh citra merek dan studi kelayakan bisnis berpengaruh terhadap keputusan pembelian masyarakat di Makassar? 


\section{Tujuan Penelitian}

Tujuan penelitian ini adalah:

1. Untuk mengetahui pengaruh studi kelayakan bisnis usaha waralaba terhadap keputusan pembelian masyarakat Makassar.

2. Untuk mengetahui pengaruh citra merek dan studi kelayakan bisnis terhadap keputusan pembelian masyarakat di Makassar.

\section{TINJAUAN PUSTAKA}

Studi kelayakan bisnis merupakan penelitian yang bertujuan untuk memutuskan apakah sebuah ide bisnis layak untuk dilaksanakan atau tidak (Umar, 2009), hal ini didasari dari ide yang bisa memberikan manfaat (profit) bagi stakeholder. Studi kelayakan bisnis merupakan langkah awal sebelum memulai rencana bisnis. Ada beberapa aspek yang harus dinilai sebelum mendapatkan kesimpulan dari studi kelayakan bisnis ini yaitu; aspek hukum, apek lingkungan, aspek pasar dan pemasaran, aspek teknis dan teknologi, aspek manajemen dan sumberdaya manusia, serta aspek keuangan.

Analisis aspek-aspek dalam studi kelayakan bisnis saling berintegrasi (Umar, 2009), sehingga jika terjadi kesalahan dalam salah satu aspek makan akan berpengaruh terhadap aspek yang lainnya.

Keterkaitan antar satu aspek dengan aspek lainnya dalam dilihat pada gambar berikut :

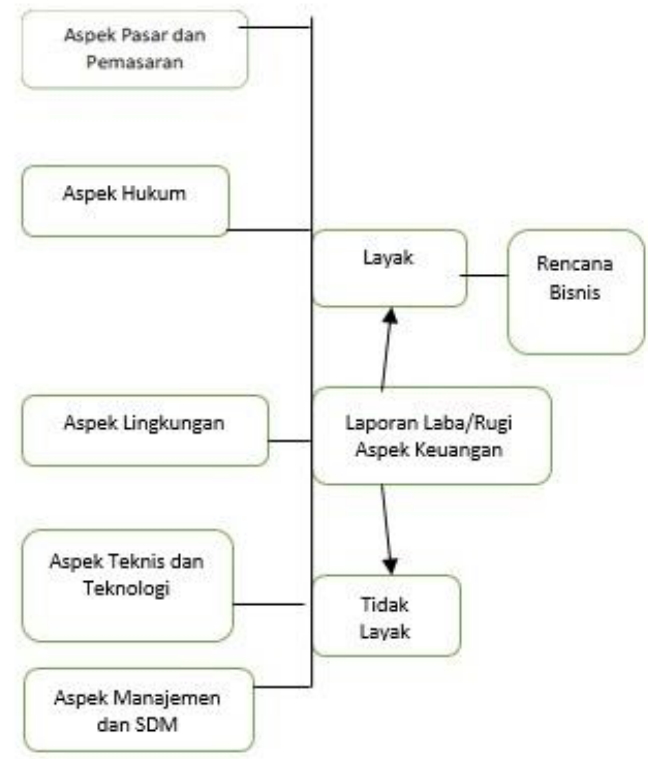

Gambar 1. Studi kelayakan bisnis

Studi kelayakan bisnis adalah sebuah ide bisnis yang memberikan manfaat besar bagi pemangku kepentingan (stakeholder) dan minim kerugian sehingga ide bisnis ini layak atau tidak untuk dilaksanakan, sedangkan menurut Ibrahim dalam Gumelar (2016) studi kelayakan bisnis adalah kegiatan untuk menilai sejauh mana manfaat yang dapat diperoleh dalam melaksanakan suatu kegiatan usaha atau proyek.

Studi kelayakan bisnis tidak hanya diperlukan oleh pemrakarsa bisnis tetapi juga mampu memberikan manfaat oleh beberapa pihak yang membutuhkan kelayakan dengan berbagai kepentingan (Raharjo, 2009). Bagi pelaku bisnis mendapatkan manfaat dari kesimpulan studi kelayakan bisnis apakah bisnis ini layak untuk dijalankan dan investasi yang dilakukan menjanjikan, bagi investor dapat mengambil langkah apakah memasukkan modal memberikan keuntungan di masa akan datang, bagi kreditor bisa mengambil langkah memberikan kredit kepada pelaku bisnis karena kreditor dapat menganalisa 


\section{PAY Jurnal Keuangan dan Perbankan. Vol. 2 No. 2, Desember 2020}

berapa banyak penjualan, laba rugi yang di dapatkan oleh debitur dengan begitu kredit macet dapat dihindari, sedangkan bagi pemerintah bisa mengambil langkah memberikan izin usaha ketika semua aspek penilaian dapat terpenuhi dan memberikan banyak manfaat kepada masyarakat.

Dalam studi kelayakan bisnis terdapat beberapa aspek yang saling berintegrasi, proses analisis setiap aspek saling berketerkaitan sbb;

1. Aspek pasar sendiri membutuhkan analisis potensi pasar, bentuk pasar, perkiraan penjualan yang bisa dicapai perusahaan dan perkiraan market share yang bisa dikuasai perusahaan.

2. Dalam aspek Hukum berguna untuk menganalisis kemampuan pelaku bisnis dalam memenuhi ketentuan hukum dan perizinan yang diperlukan untuk menjalankan bisnis di wilayah tertentu seperti bagaimana bisnis dilakukan dan apakah bisnis yang dilakukan sesuai dengan peraturan dan perundangundangan yang berlaku.

3. Aspek Lingkungan Industri menganalisis kesesuaian dengan lingkungan sekitar dimana ide bisnis itu di jalankan serta dampak bagi lingkungan juga harus terjaga. Indicator aspek lingkungan industry yang dilihat adalah ancaman masuk pendatang baru, persaingan sesama ide bisnis dalam industrinya, ancaman dari produk pengganti, kekuatan tawar menawar pembeli dan pemasok.

4. Aspek Teknis dan teknologi menganalisis kesiapan teknis dan ketersediaan teknologi yang dibutuhkan untuk menjalankan bisnis. Indicator yang dinilai pada aspek ini berupa penentuan strategi produksi dan perencanaan produk, proses pemilihan teknologi, penentuan kapasitas produksi yang optimal, letak pabri yang layoutnya, rencana operasional dalam hal jumlah produksi, pengawasan kualitas produk baik dalam bentuk barang dan jasa.

5. Aspek Manajemen dan sumberdaya Manusia, Aspek ini menitiberatkan pada Analisa pada tahap-tahap pelaksanaan bisnis dan kesiapan tenaga kerja, baik pada tenaga kerja kasar, maupun tenaga kerja terampil yang diperlukan untuk menjalankan bisnis, penentuan deskripsi pekerjaan, kebijakan rekrutmen, produktivitas kerja, program pelatihan dan pengembangan, perencanaan karir, keselamatan dan kesehatan kerja serta mekanisme PHK.

6. Aspek keuangan pada aspek ini berdasar pada Analisa pada besarnya biaya investasi dan modal kerja serta tingkat pengembalian investasi dari bisnis yang dijalankan berupa kebutuhan dana serta sumbernya, penentuan kebijakan aliran kas, kajian mengenai biaya modal, penilaian rencana bisnis melalui metode Prafability Index (PI),Net Present Value (NPV), Internal rate of return (IRR), Payback Period (PP). Penentuan leasing atau beli terhadap aktiva tetap serta proses pemilihan prioritas bisnis hal ini dilakukan untuk mengetahui perkiraan pendanaan dan aliran kas proyek bisnis sehingga dapat diketahui layak atau tidaknya rencana bisnis yang di maksud (Suliyanto, 2010).

7. Keputusan pembelian meruapakan tujuan dari strategi pemasaran menurut (Ying Fan \& Yixuan Li, 2009) bahwa keputusan pembelian di dasari oleh pengalaman dari konsumen sebelumnya mereka akan mencari review toko yang baik sebelum melakukan keputusan 
PAY Jurnal Keuangan dan Perbankan. Vol. 2 No. 2, Desember 2020

pembelian. . Para pemula yang baru belajar atau orang yang akan membeli sebuah barang dengan mencari informasi terlebih dulu dari orang-orang yang berpengalaman atau sudah memiliki, karena mereka lebih percaya pada review/ komentar dari mereka yang berpengalaman sebelum memutuskan untuk membeli. Biasanya mereka akan mencari tahu dengan menulis di dinding grup facebok komunitas sesuai dengan yang mereka inginkan untuk mendapatkan respon dari anggota lainnya yang berpengalaman. (Mulyandi, 2020) membagi ulasan konsumen online menjadi empat jenis, yaitu konten, kredibilitas, ketepatan waktu,dan kuantitas. Ia menemukan bahwa konten, kredibilitas dan kuantitas membawa positif yang signifikan berpengaruh terhadap keputusan pembelian, tetapi ketepatan waktu tidak berpengaruh signifikan terhadap keputusan pembelian.

Penjelasan hubungan yang terdapat dalam kerangka pikir ini, bahwa penelitian ini memuat :

1. Variabel $\mathrm{X}$ adalah variabel bebas (independent variable):

a. Variabel X1 yaitu :Kelayakan Bisnis, indikator yang diteliti adalah tempat usaha, keramahan, pelayanan, sanitasi, harga.

b. Variabel X2 yaitu Citra merek, indikatornya review, reputasi toko, ulasan pembeli, pelanggan tetap dan pelayanan.

2. Variabel $\mathrm{Y}$ adalah variabel terikat (dependent variable), yaitu Keputusan pembelian yang indikatornya kebutuhan, kesehatan dan keamanan, rekomendasi, keunggulan serta stok barang.
Berorientasi dari kerangka berpikir di atas, maka penelitian ini menganalisis Analisis Studi Kelayakan Bisnis Usaha Waralaba dan Citra Merek terhadap Keputusan Pembelian "Alpokatkocok_Duobig" Di Makassar. Hal ini dapat dikatakan penelitian ini menganalisis faktor-faktor yang mempengaruhi kesuksesan usaha dalam pembatasan social berskala besar.

\section{METODE ANALISIS}

Adapun metode yang digunakan yaitu:

\section{a. Analisis Aspek-aspek dalam studi} kelayakan

1. Aspek pasar dan Pemasaran

Data tentang target pasar, jumlah permintaan dan penawaran, kualitas dan spesifikasi produk serta tentang penetapan harga dan promosi.

2. Aspek Teknis dan Tekhnologi

Data tentang deskripsi produk, penentuan lokasi, dan lay out fasilitas.

3. Aspek Manajemen dan Sumbe Daya Manusia

Data tentang struktur organisasi, job description, sistem kompensasi, program pengembangan karyawan.

4. Aspek Hukum dan Legalitas

Data tentang jenis-jenis perizinan yang dimiliki

5. Aspek Keuangan dan Ekonomi

Data tentang penyusunan modal kerja dan modal investasi

b. Alat Analisis Kelayakan Investasi

1. Metode PP (Payback Period)

Teknik Penilaian terhadap jangka waktu (periode) pengembalian investasi suatu proyek atau usaha.

$$
\mathrm{PP}=\frac{\text { Jumlah Investasi } x 12 \text { buln }}{\text { Aliran Kas Bersih }}
$$

Kriteria penilaian pada payback period adalah;

- Jika waktu payback period < waktu maksimum, maka usulan proyek tersebut dapat diterima. 
PAY Jurnal Keuangan dan Perbankan. Vol. 2 No. 2, Desember 2020

- Jika waktu payback period > waktu maksimum, maka usulan proyek tersebut dapat ditolak.

2. Metode B/C Ratio

Metode B/C Ratio merupakan perbandingan antara total pendapatan selama masa tertentu dengan capital lay out.

$\mathrm{B} / \mathrm{C}$ Ratio $=\frac{T R}{T C}$

Kriteria penilaian $\mathrm{B} / \mathrm{C}$ ratio adalah;

- Jika B/C >0 maka usaha layak di usakan

- Jika $\mathrm{B} / \mathrm{C}<0$ maka usaha tidak layak diusahakan.

3. Metode NPV (Net Present Value)

Metode ini merupakan net benefit yang telah didiscount dengan menggunakan social opportunity cost of capital sebagai discount factor.

NPV= Total PV aliran Kas BersihTotal PV Investasi

Kriteria penilaian NPV adalah;

- Jika NPV > 0 Maka Investasi diterima

- Jika NPV 0, Maka Investasi ditolak.

4. Metode IRR (Internal Rate of Return)

Metode IRR adalah tingkat bunga yang akan diterima sama dengan jumlah nilai sekarang dari pengeluaran modal (PV Capital Outlays)

$$
\mathrm{IRR}=\mathrm{PI}-\mathrm{CI} \times \frac{P 2-P 1}{C 2-C 1}
$$

Keterangan :

$\mathrm{P} 1=$ Tingkat Bunga 1

$\mathrm{P} 2=$ Tingkat Bunga 2

$\mathrm{C} 1=\mathrm{NPV} 1$

$\mathrm{C} 2=\mathrm{NPV} 2$

Kriteria Penilaian IRR adalah;

- Jika IRR > suku bunga yang telah ditetapkan, maka investasi diterima.
- Jika IRR < suku bunga yang telah ditetapkan, maka investasi ditolak

\section{HASIL PENELITIAN}

ANOVA $^{b}$

\begin{tabular}{|c|c|c|c|c|c|c|}
\hline \multicolumn{2}{|c|}{ Model } & $\begin{array}{l}\text { Sum of } \\
\text { Squares }\end{array}$ & df & $\begin{array}{c}\text { Mean } \\
\text { Square }\end{array}$ & $F$ & Sig. \\
\hline \multirow[t]{3}{*}{1} & Regression & 67.051 & 1 & 67.051 & 13.542 & $.001^{\mathrm{a}}$ \\
\hline & Residual & 237.669 & 48 & 4.951 & & \\
\hline & Total & 304.720 & 49 & & & \\
\hline \multicolumn{7}{|c|}{$\begin{array}{l}\text { a. Predictors: (Constant), Studi Kelayakan } \\
\text { Bisnis Usaha Waralaba Alpokatkocok } \\
\text { Duobig }\end{array}$} \\
\hline \multicolumn{7}{|c|}{$\begin{array}{l}\text { b. Dependent Variable: Buying } \\
\text { Purchasing }\end{array}$} \\
\hline
\end{tabular}

\begin{tabular}{|l|r|r|r|r|r|}
\hline Model & $\begin{array}{c}\text { Sum of } \\
\text { Squares }\end{array}$ & df & $\begin{array}{c}\text { Mean } \\
\text { Square }\end{array}$ & F & Sig. \\
\hline $1 \quad$ Regression & 55.350 & 1 & 55.350 & 10.654 & $.002^{\mathrm{a}}$ \\
Residual & 249.370 & 48 & 5.195 & & \\
Total & 304.720 & 49 & & & \\
\hline
\end{tabular}
a. Predictors: (Constant), Citra Merek
b. Dependent Variable: Buying
Purchasing

Berdasarkan tabel output Anova di atas diketahui nilai sig sebesar $001<0.05$ dan $002<0.05$ sehingga pengambilan keputusan dalam uji F bahwa Studi Kelayakan Bisnis dan Citra Merek secara simultan berpengaruh terhadap Buying Purchasing maka prasyarat analisis linear terpenuhi.

Pengambilan keputusan uji $F$ diketahui bahwa nilai $\mathrm{F}$ hitung dari tabel anova adalah 13.542 dan $10.654>\mathrm{F}$ tabel 3.19 sehingga hipotesis diterima atau studi kelayakan bisnis usaha waralaba dan citra merek secara simultan berpengaruh pada buying purchasing.

1. Aspek Pasar dan Pemasaran

Aspek pasar dan pemasaran untuk menilai apakah usaha yang melakukan investasi ditinjau dari pasar layak atau tidak. Dari hasil uji anova yang berasal dari 50 responden di atas bahwa citra merek yang terkenal memiliki pengaruh positif terhadap keputusan pembelian masyarakat. Usaha 
Waralaba Alpokatkocok_Duobig telah memiliki 11 cabang di daerah Sulawesi Selatan hingga Sulawesi Barat dan satu di ambon hal ini dikarenakan untuk memenuhi permintaan pasar. Pemilihan Kualitas bahan baku dari supplier berupa alpokat merupakan hal yang paling penting dalam usaha ini, daging alpukat harus tebal dan tidak memiliki rasa pahit sehingga pemilik usaha dari waralaba ini mengambil alpukat yang berasal dari Maumere. Alpukat dari Maumere Nusa Tenggara Timur terkenal dengan alpukat mentega yang memiliki daging buah yang manis dan tebal sehingga kualitas dari produk usaha ini begitu enak dan sesuai dengan permintaan pasar selain itu kemasannya memiliki desain yang menarik dan praktis serta memiliki brand.

Selain kualitas produk yang dihasilkan enak, usaha waralaba ini juga memasarkan produknya di jasa layanan Aplikasi grabfood atau gofood dengan berbagai promo yang menarik yang membuatnya semakin terkenal sehingga mampu berkembang di berbagai daerah walaupun memiliki banyak pesaing. Alpokatkocok-Duobig mempunyai peluang dalam pengembangan usahanya, maka dapat di Tarik kesimpulan dilihat dari aspek pasar dan pemasaran bahwa usaha ini layak untuk diusahakan.

2. Aspek Manajemen dan Sumber Daya Manusia

Struktur organisasi, pada Usaha Waralaba Alpukatkocok-duobig masih sederhana setiap cabang memiliki 2 karyawan jadi apabila ditotalkan 24 karyawan, setiap karyawan memiliki tugas kerja yang berbeda,2 untuk aspek balas jasa pemilik usaha ini memberikan sistem bonus diluar gaji bulanan atas kinerja yang karyawan miliki, setiap cabang memiliki kasir yang sudah terpercaya yang merupakan karyawan yang sudah loyal terhadap usaha ini sebagai pengembangan dari karirnya dan seorang karyawan yang membuat minuman. Karyawan di usaha ini harus memiliki jiwa pekerja keras, bertanggung jawab dan jujur yang merupakan aspek dari kebutuhan tenaga kerja, sehingga usaha ini layak dijalankan.

\section{Aspek Teknis dan Teknologi}

Dalam pemilihan lokasi usaha sang pemilik selalu memilih lokasi di depan perkantoran contonya seperti di jl. Amanagappa depan kantor Kejaksaan Negeri Makassar, atau di daerah keramaian seperti dalam Mall Trans Daya Makassar ataukah di depan toko kue Adi Jaya jl. Sultan hasanuddin Gowa tepat nya di jalan poros Propinsi Makassar Gowa yang memiliki jumlah penduduk yang padat, akses jalan yang lancar. Pemilihan teknologi pada usaha ini sudah menggunakan teknologi yang efisien dan praktis dalam segi pengepakannya yang menggunakan sealer cup namun untuk mencampur adonan masih menggunakan blender dan alat sederhana. Dalam segi pencatatan arus kas atau pembukuan masih sederhana dengan buku, namun untuk pembayaran bisa tunai ataukah menggunakan mesin EDC ( Electronic Data Capture) yang merupakan mesin penerima pembayaran nontunai dari kartu kredit atau kartu debit. Berdasarkan penilaian dari aspek teknis dan teknologi maka usaha ini layak untuk di jalankan.

4. Aspek Hukum dan Legalitas Dalam mendirikan sebuah usaha harus memiliki aspek hukum dan legalitas, pada usaha ini pemilik 
memilih menjadi usaha perseorangan karena usaha masih sederhana dan tidak memiliki pernyataan khusus, usaha ini telah mendapatkan izin di tokoh masyarakat setempat dan sudah memiliki SIUP (surat Izin Usaha Perdagangan) serta Hak paten Logo dan Brand, sehingga berdasarkan aspek hukum dan legalitas maka usaha ini layak di jalankan.

5. Aspek Keuangan dan Ekonomi Aspek keuangan pada usaha bisnis waralaba Alpokatkocok_Duobig sudah memperhitungkan dari segi investasi dan modal yang akan dikeluarkan selain itu pemiik juga melakukan pinjaman pada pihak perbankan yang akan dikembalikan secara bertahap dalam waktu yang di tentukan. Pemilik juga sudah merasakan pengembalian investasi usaha sehingga pemilik sudah balik modal dan mendapatka laba sesuai yang diinginkan.

Usaha ini jika dilihat dari segi Aspek Ekonomi mampu meningkatkan pendapatan keluarga karyawan yang bekerja pada usaha ini dan membantu pemerintah dalam mengurangi pengangguran sehingga dapat dikatakan usaha ini layak di jalanka dari segi aspek keuangan dan ekonomi.

6. Analisis Kelayakan Investasi

a. Perhitungan Payback Period

Berdasarkan pengembalian investasi suatu usaha dapat diketahui bahwa Payback Period (PP) "Usaha Alpokatkocok_Duobig" adalah:

Investasi Awal 1,075,088,239

Arus Kas Bersih tahun $1 \underline{467,588,934}$ $607,499,305$

Arus Kas Bersih tahun $2 \quad \underline{514,637,747}$ $92,861,558$

Arus Kas Bersih tahun $3 \quad 566,391,442$ $-473,529,884$
Payback Period $(\mathrm{PP})=2$ Tahun 5 bulan 6 hari dapat diartikan bahwa usaha ini layak untuk dijalankan karena berada di bawah umur ekonomis pengembalian modal yaitu 5 tahun, Hal ni sesuai dengan Abdul Choliq,dkk(2004) yang menyatakan bahwa payback period adalah lamanya jangka waktu kembalinya investasi dapat kembali atau dikeluarkan.

\section{b. Perhitungan $\mathrm{B} / \mathrm{C}$ ratio}

$\mathrm{B} / \mathrm{C}$ ratio adalah perbandingan total pendapatan selama masa tertentu dengan capital out lay sbb;

$\mathrm{B} / \mathrm{C}$ ratio $=\frac{T R}{T C}$

Sehingga $\mathrm{B} / \mathrm{C}$ ratio dari bisnis waralaba "Alpokatkocok_Duobig" dapat dilihat pada tabel 1 di bawah ini adalah

Tabel 1. Perhitungan B/C ratio usaha waralaba Alpokatkocok_Duobig.

\begin{tabular}{|c|c|}
\hline \multirow{3}{*}{$\mathrm{B} / \mathrm{C}$ ratio tahun 1} & $\underline{1,567,852,832}$ \\
\hline & $1,045,088,239$ \\
\hline & 1.500211 \\
\hline \multirow{3}{*}{$\mathrm{B} / \mathrm{C}$ ratio tahun 2} & $1,724,638,115$ \\
\hline & $1,149,597,063$ \\
\hline & 1.500211 \\
\hline \multirow{3}{*}{$\mathrm{B} / \mathrm{C}$ ratio tahun 3} & $\underline{1,897,101,927}$ \\
\hline & $1,264,556,769$ \\
\hline & 1.500211 \\
\hline \multirow{3}{*}{$\mathrm{B} / \mathrm{C}$ ratio tahun 4} & $\underline{2,086,812,119}$ \\
\hline & $1,391,012,446$ \\
\hline & 1.500211 \\
\hline \multirow{3}{*}{$\mathrm{B} / \mathrm{C}$ ratio tahun 5} & $\underline{2,295,493,331}$ \\
\hline & $1,530,113,691$ \\
\hline & 1.500211 \\
\hline
\end{tabular}

Didapatkan hasil $\mathrm{B} / \mathrm{C}$ ratio tahunan sebesar $1,50>0$ hal ini menunjukkan bahwa usaha ini menguntungkan dan 
PAY Jurnal Keuangan dan Perbankan. Vol. 2 No. 2, Desember 2020

layak untuk di jalankan karena $\mathrm{B} / \mathrm{C}$ ratio lebih besar dari nol.

\section{c. Perhitungan NPV (Net Present Value)}

Didapatkan hasil sebesar NPV= 5,047,590,444 > 156.7852.832 maka usaha ini layak untuk di jalankan, karena NPV lebih besar daripada investasi awal dapat dilihat pada tabel 2 di bawah ini;

Tabel 2. Perhitungan NPV usaha waralaba Alpokatkocok_Duobig

\begin{tabular}{|c|c|c|c|}
\hline Tahun & Proceed & $\begin{array}{l}\text { Df } \\
15 \% \\
\text { (tabel } \\
\text { Pvifa) }\end{array}$ & PV \\
\hline 1 & $467,588,934$ & 0.8696 & $406,615,337$ \\
\hline 2 & $514,637,747$ & 1.6257 & $836,646,585$ \\
\hline 3 & $566,391,442$ & 2.2832 & $1,293,184,940$ \\
\hline 4 & $623,320,506$ & 2.8550 & $1,779,580,045$ \\
\hline 5 & $685,942,477$ & 3.3522 & $2,299,416,370$ \\
\hline \multicolumn{3}{|l|}{ NPV } & $6,615,443,276$ \\
\hline
\end{tabular}

Sumber: Data primer, diolah 2020.

Berdasarkan tabel 2 tersebut nilai NPV sebesar 6.615.443.276 - 156.7852.832= 5,047,590,444 dimana lebih besar dari investasi awal dan bisnis ini menguntungkan. Menurut Hanle dan Spash (1993) nilai NPV merupakan cerminan laba bersih yang didapatkan oleh pelaku bisnis saat kondisi terakhir laba dihitung.

\section{d. Perhitungan IRR (Internal Rate Of} return)

IRR bisnis "Alpokatkocok_Duobig" dapat dilihat pada tabel $3 \mathrm{sbb}$;

Tabel 3. Perhitungan IRR usaha waralaba Alpokatkocok_Duobig

\begin{tabular}{|c|l|c|l|}
\hline Tahun & Proceed & $\begin{array}{l}\text { faktor } \\
\text { diskonto } \\
\mathbf{2 4 \%}\end{array}$ & \\
\hline $\mathbf{1}$ & $467,588,934$ & 0.806 & $376,876,681$ \\
\hline $\mathbf{2}$ & $514,637,747$ & 0.65 & $334,514,536$ \\
\hline $\mathbf{3}$ & $566,391,442$ & 0.524 & $296,789,115$ \\
\hline $\mathbf{4}$ & $623,320,506$ & 0.423 & $263,664,574$ \\
\hline
\end{tabular}

\begin{tabular}{|c|c|c|c|}
\hline 5 & $685,942,477$ & 0.341 & $233,906,385$ \\
\hline \multicolumn{3}{|c|}{ Total PV } & $1,505,751,290$ \\
\hline \multicolumn{3}{|c|}{ Investasi Awal } & $1,567,852,832$ \\
\hline \multicolumn{3}{|l|}{ NPV } & $-62,101,542$ \\
\hline Tahun & Proceed & $\begin{array}{c}\text { faktor } \\
\text { diskonto } \\
20 \%\end{array}$ & \\
\hline 1 & $467,588,934$ & 0.833 & $389,501,582$ \\
\hline 2 & $514,637,747$ & 0.694 & $357,158,596$ \\
\hline 3 & $566,391,442$ & 0.579 & $327,940,645$ \\
\hline 4 & $623,320,506$ & 0.482 & $300,440,484$ \\
\hline 5 & $685,942,477$ & 0.402 & $275,748,876$ \\
\hline \multicolumn{3}{|c|}{ Total PV } & $1,650,790,182$ \\
\hline \multicolumn{3}{|c|}{ Investasi Awal } & $1,567,852,832$ \\
\hline \multicolumn{3}{|l|}{ NPV } & $82,937,350$ \\
\hline \multicolumn{3}{|c|}{ Perhitungan Interpolasi } & \\
\hline $\begin{array}{l}\text { Selisih } \\
\text { bunga }\end{array}$ & Selisih PV & $\begin{array}{l}\text { Selisih PV } \\
\text { dengan } \\
\text { Investasi } \\
\text { awal }\end{array}$ & \\
\hline 20 & $1,650,790,182$ & $1,650,790,182$ & \\
\hline 24 & $1,505,751,290$ & $1,567,852,832$ & \\
\hline 4 & $145,038,892$ & $82,937,350$ & \\
\hline
\end{tabular}

Berdasarkan tabel 3 diatas bisnis layak dijalankan karena IRR 22.29\%> 20\% dimana tingkat keutungan lebih besar dari yang dikehendaki hal ini sesuai dengan (Suliyanto, 2010) yang menyatakan bahwa IRR dapat dikatakan layak ketika yang di dapatkan lebih besar dari yang dikehendaki.

\section{KESIMPULAN DAN SARAN}

Hasil yang di dapatkan dari keseluruhan aspek yang di teliti yaitu:

1. Aspek pasar dan pemasaran, aspek manajemen dan sumberdaya manusia, aspek teknis dan teknologi, aspek hukum dan legalitas, serta aspek keuangan dari usaha bisnis waralaba Alpokatkocok_duobig ini telah memenuhi syarat dan menunjukkan bahwa usaha ini layak di jalankan. 


\section{PAY Jurnal Keuangan dan Perbankan. Vol. 2 No. 2, Desember 2020}

2. Berdasarkan hasil analisis kelayakan investasi baik itu berupa payback period, B/C ratio, perhitungan NPV dan IRR serta uji anova dimana studi kelayakan bisnis dan citra merek yang berpengaruh positif terhadap keputusan pembelian, dapat disimpulkan bahwa bisnis usaha waralaba Alpokatkocok_duobig layak untuk dijalankan dan potensial untuk dikembangkan.

3. Penelitian ini membutuhkan beberapa perbaikan pada aspek Teknik dan teknologi yaitu pada proses produksi sebaiknya mentransformasi mesinnya dengan mesin yang lebih modern dang canggih sehingga bisa menekan biaya produksi dan hasil yang lebih produktif, oleh karena itu dibutuhkan penelitian yang lebih mendalam tentang aspek teknis dan teknologi agar bisnis alpokatkocok_duobig bisa mendapatkan keuntungan yang lebih banyak lagi

\section{DAFTAR PUSTAKA}

Choliq, Abdul. 2014. Pengantar Manajemen. Penerbit Ombak: Yogyakarta.

Gumelar, Brian.2016. Pengaruh Brand Image dan Celebrity Endorser TerhadapKeputusan Pembelian Kosmetik Wardah. Skripsi S1. Fakultas Ekonomi Universitas Negeri Yogyakarta: Yogyakarta.

Hanafi, M.A.N. 2019. Analisis Kelayakan Investasi pada PT. Bank Mandiri (Persero) Tbk yang Terdaftar di Bursa Efek Indonesia (BEI). POINT Jurnal Ekonomi dan Manajemen, Vol. 1 No. 1. https://ejournals.umma.ac.id/index .php/point/article/view/120.
Hanley, ND and Spash,C. 1993. Cost Benefic Analysis and the environment. Edward Elgar, Cheltenham: UK.

Horne, Van James C. John M. 1997. Prinsip-Prinsip Manajemen Keuangan. Edisi Sembilan, Salemba Empat : Jakarta.

Lusty, 2012. Pemahaman Akuntansi dan Kesadaran Membayar Pajak Terhadap Kepatuhan Wajib Pajak UMKM di kota Yogyakarta.Skripsi Univrsitas PembangunanVeteran" Yogyakarta.

Musthikaningtyas, R.P., danTri, D.W. 2015. Pembuatan Minuman Fungsional Liang The Daun Salam (Eugenia polyantha) dengan Penambahan Filtrat Jahe dan Filtrat Kayu Secang. Jurnal Pangan dan Agroindustri, 3(4): 1458-1464.

Raharjo, Budi. 2009. Analisis Kelayakan Usaha dan strategi pengembangan Industri Kecil Meubel di Kecamatan Suruh Kabupaten Semarang. Skripsi, Universitas Negeri Semarang : Semarang.

Suliyanto. 2010. Studi Kelayakan Bisnis pendekatan praktis. CV Andi: Yogyakarta.

Umar, Husein. 2009. Studi Kelayakan Bisnis Teknik menganalisis kelayakan rencana bisnis secara komprehensif. PT. Gramedia Pustaka Utama: Jakarta. 